\title{
An Emerging Extraordinary Villain Transnational Organized Crime in the Perspective of Al-Shabaab Terrorist in SADC Regional. The Strategies of Scuffling Terrorism in the SADC Region
}

\author{
Prosper Ng'andu \\ University of Zambia Great East Road Campus, \\ PO Box 32379 Lusaka-Zambia
}

\begin{abstract}
Terrorism has ancient genesis since the Roman empires. The phenomenon has assumed an extraordinary villain among the pervasive cross border crime that has not spared SADC states. The survival of terror by most member states of SADC does not imply that they are terror resistance; therefore, panacea strategic framework is cardinal to combat the vampire of al-Shabaab terrorists and insurgents. In examining the regional strategies of SADC in scuffling terrorism, this article explore the concept of "Old War", which has been likened to "Lion attack" and the "New War", which also likened to a "snake bite" on human being. The paper examines the secondary data consisting mostly of scholarly writing, ad-hoc reports and other publications on terrorism. When conducting content analyses for the qualitative data, the author seeks to be as transparent as possible about the methods employed, particularly pertaining to definitions and codification ameliorate scholarly replication and verification of the study and its conclusions. The study established that though, SADC has structured Protocols and Counter Terrorism Strategy Framework underpinned on four pillars of UN to prevent and combat the threats of terrorism, it is a challenge for member states to thwart the phenomenon because of financial capacity, inadequate legislature, porous borders, perceived social exclusion, emerged nontraditional security like epidemic and pandemic, climate change, poverty, and diseases that occupy priority. The article is an interpretive phenomenological paper in which the epistemology is acquired by immersing self in some investigation of the phenomenon of terrorism.
\end{abstract}

Keywords:- Terrorism, SADC, Snake and Lion, insurgent al-Shabaab and Al-Qaeda.

\section{INTRODUCTION}

The September 11, 2001 terrorism crashing northern façade of the World Trade Center's North Tower, South Towers (WTC Twin Tower) and the Pentagon in the United States of America (USA) was a wakeup call globally to terrorism threats as key security threat to human kind. However, prior to that, there were audacious terrorism attacks in Africa launched by notorious Al Qaeda in Dares-Salaam, Tanzania and Nairobi, Kenya at the Embassies of US, killing two hundred and forty people, including twelve Americans and injuring four thousand five hundred and seventy four through bombings in 1998 (Hoofemen, 2012; \& Walt \& Solomon, 2014). The paper focuses on the emerging al-Shabaab terrorists as well as other insurgents, and the strategies formulated by SADC member states to wrestling the phenomenon which is ponder as the "new" war. Before, focusing on the villain al-Shabaab terrorists and the strategies by SADC, the article tackles definition of terrorism by different scholars, the brief anatomy of terrorism, and terrorism in contemporary age in focus of "new wars", hereafter, al-Shabaab terrorism activists and structured SADC strategies to scuffle the phenomenon in the region. The conclusion is drawn from mainly the activities of al-Shabaab and how prepared SADC region is in the preventing and scuffling one of the pervasive extraordinary villain transnational border crimes.

Kaldor (2013) one of the scholars of "New" and "Old" wars depicts, a "New war" as mixture of war, involving global, local, public and private actors in a manner of organized crime and massive violation of human rights, whereas "Old wars" were wars fully funded and fought by the regular Army of the state with the support of international Law. The media has documented a number of "New" war in term of evolving notion of terrorism being perpetuated by myriad of actors across Africa and SADC in particular mainly the al-Shabaab terrorist group of Somalia (Ritchie, 2019).

The ramification of al-Shabaab terrorist with connection to Boko Haram in Nigeria and Al-Quad has precipitated public discussion and attracted international community especially the United States of America (USA) to shift focus to Southern African countries with a view to influence and fund counterterrorism policy making. "AlShabaab terrorist group has been a extending threats to other countries beside Somalia, and in July 2010 the vampire al-Shabaab instigated attacks on Uganda thereby, killing 75 civilian gathered to watch a world cup" (Petrich, 2020). This shows that terrorists group targets innocent civilian, hitherto violating human rights of ordinary people. In as much as the attacks of terrorists are merciless and cause displacements of thousands of civilians, the UN recently cautioned Swaziland against acting the law in the name of suppression of terrorist that would violate the 
human rights of perpetrators. Amnesty International (2009) the Amnesty International and Human Rights Institute of International Association argue that the suppression of terrorist human rights is over inherently repressive and breach of the country obligation under international and national human rights Law and the Swaziland Constitution with the Suppression of Terrorism Act No 3 0f 2008. According to Oxford Dictionary terrorism is defined as "the unlawful use of violence and intimidation especially against civilians, in pursuit of political claim” (Ritchie, 2019).

\section{DEFINITION OF TERRORISM}

There has been complex and controversial with the term of terrorism which has yielded a stigma due to its inherent violence and ferocity. Jenkins defines terrorism as a systematic use of violence aimed at instilling fear and intimidation among wide audience so that certain political objectives are attained. "The system of violence, intimidation can be used by Intelligence services, Police, religious groups, armies, revolutionaries and nationalistic to achieve the desired goal". However, the dictionary definition lacks international consideration. The definition of terrorism has no consensus as the word meaning depends on the application, either one's enemies or opponents, hence, intrinsically attracting negative connotations and it is emotionally and politically charged (Hoffman, 1998).

Title twenty two of the US code defines terrorism as "politically motivated violence perpetrated in a clandestine manner against non combatants. The terror is committed to create fearful state of mind in general populace apart from the victims" (Ruby, 2003).

The definition of terror has been a complex. Jacobin "Reign of Terror", which came after French Revolution in 1789, was the first to apply the word "terror". International Legal attempted to grapple with the difficulty of defining the word during the International Conference for the Unification of Renal Law, and a number of meetings were undertaken in Europeans capitals in 1920s and 1930s. Academics, Lawyers, International bodies like UN, regional organizations, national legislatures have produced by 1988 a total of one hundred and nine definition, however, the attempts to arrive at legal definition, even after forcing on September, 11 terrorism, it has failed (Goldv \& Williams, 2004, p270). The UN 1985-2004, Security Council tried to adopt ranged mechanism to tackle the threat of terrorism to peace and, but failed to remedy the challenges of defining terrorism. On other hand, the Council permitted states to unilaterally define the phenomenon in national law (Saul, 2005). Some scholarly definitions states;

> Whittaker (2012 defines terrorism as the unlawful use of force or violence against persons or property to intimidate or coerce a Government, the civilian population, or any segment thereof, in furtherance of political or social objectives (FBI).

$>$ US Department of Defence postulates that the calculated use of violence or the threat of violence to inculcate fear, intended to coerce or intimidate
Government or Societies as to the pursuit of goals that are general political, religious or ideological or premeditated, politically motivated violence perpetuated against non combat targets by sub-national groups or clandestine agents, usually intended to influence on audience;

$>$ the use or threat, for the purpose of advising a political, religion or ideological cause, of action which involves serious violence against any person or property (UK Government);

$>$ Walter Laqueur) states that terrorism contributes the illegitimate use of force to achieve a political objective when innocent people are targeted; and

a strategy of violence designed to promote desired outcomes by instilling fear in the public at large (Walter Reich). Brain Jenkins argues, the use or threatened use of force designed to bring about political change.

Generally, the catching words in all the definition are that terrorism involves use of violence or threats aimed at instilling fear or intimidate in the general population or Government with a view to gain political objectives. The fact is that a grouping involving in terrorist activities has some cause to attain. Terrorism occurs where there is oppression and that grievance by the affected group need to be addressed. Terrorism can be opposition reaction or resistance to the state action or the state can sponsor terrorism to favor its interests. The opposition will deploy the symbolic threats with predetermined terrorism for the purpose of political change (Zalma, 2020). The phenomena takes multiple forms with many causes rooted in political differences, religious, economic or social in which one community feel unfairly treated. The extremism of Islamist militant group al-Shabaab in Somalia carried out a string of attacks across the region. The group, which is allied to alQaeda, was pushed out of most of the main towns it once controlled by UN forces (BBC, 2017).

\section{AN ANATOMY OF TERRORISM}

The scourge of terrorism dates way back before middle age when rulers used terrorism acts with political intentions as a tool for administration and external expansion whereas, the oppressed used the same terrorist means to fight against tyranny. During AD, Jewish Fanatics poisoned the drinking water in the Roman Empire, thereby assassinating the Jewish aristocrats who cooperated with the ancient (Vidal, 2005). The phenomenon involving groupings of political terror and righteous killing manifested in Middle Ages, where "Brotherhood Assassins" - the Sectarian group were employed by their spiritual and political leader in Jerusalem, Hassan I Sabah, to undertake terror of murder and destruction of religious enemies (Walt \& Solomon 2014).

The history of terrorism has most of the time being disregarded and covered up, hitherto the reoccurrence after some tranquil moment, it is perceived to be a latest phenomenon (Laqueur, 2001). The eleven months period of French Revolution from September, 1793 to July, 1794, precipitated the term terrorism as the ruling Jacobins used 
violence, mass executions aimed at instilling fear and intimidation in the opponents and forced them to obey the State during the reign of terror period (BBC, 2015).

Ancient Roman Emperors Tiberius and Caligula employed political terrorist means which included death penalty, exile and dispossession of property to induce people not to resist their leadership. The Father of Roman known as Caesar on 15 March of 44 BC was assassinated by his opponent political terrorists. In mid 17 century, the powerful British politician Oliver Cronwell engaged in high handed terrorist acts to intimate and influence the resistance of Irish people and conquered Ireland. The struggle of Irish people against Britain in $17^{\text {th }}$ Century including the Spain uprising against the Napoleon Empire in $19^{\text {th }}$ Century as well as Greek Independence against Turkey Colonist in 1830's all employed terrorist struggle (Hoffman, 1998).

In the $1^{\text {st }}$ Century CE the Roman rule supporters were massacred in terrorist act by the rebel group of Jewish Zealots in Judaea Province and in $6 \mathrm{CE}$ an extreme but small terror group was formed by Josephus, Judas of Galilee more powerful than the Zealots targeted at killing of Jewish collaborators among them Priests, Sadducees, Herodias, wealth elites, the terror group was called Sicarii who would mingle with people at their festivals and murder the victims thereafter disappear in the crowds (Chaliand, 2007).

It is a well known fact that a grouping engage in terrorist act for some causes. Terrorism happens where there is an oppression and the grouping has some grievance that require attention and soon such grievances are resolved then terrorism can disappear. Starting from the $1^{\text {st }}$ century, the period of Reign of Terror, $19^{\text {th }}$ century up to now in the $21^{\text {st }}$ century, terrorist acts are audaciously conducted. A human being when desperate and confronted with a sympathetic understanding can resort to any action to attain the desired needs. It is on this premise that in this article I prescribe a terrorist as "Snake" as the operation is so secretive that the true nature and identity is concealed even to the friends. For instance, the hijackers, suicide bombers, kidnappers can launch an attack unsuspected, yet they were dinning, flying, wining or playing with friend.

A "snake" can travel with you whilst in the cabin of a bag and launch an attack on you when you have even reached. In Kandahar Hijack in India, December, 1999 Captain Devil Sharma a pilot of the plane Indian Airlines Flight 814 known as IC814 Airbus A300 was shocked when the plane was still in Indian airspace, one of the five terrorists, threatened to blow up the plane using a bomb and ordered him to fly west, while the other four terrorists in red mask held the 191 people hostage. But the terrorist boarded the Aircraft together with all the passages and crew members without knowing their motive (Press Trust India, 2015).

\section{TERRORISM IN CONTEMPORARY AGE}

The terrorism act of ancients and the contemporary terrorist have shown a difference. Some centuries ago, the terrorist was more of nationalist and religious fanatical in disposition which breaded revolutionary, as irreconcilable to the extra-ordinary villain character of the modern days which has greatly changed. The methodology being employed, aims of struggle and the people involved are quite fundamental (Neumann, 2020).

Laquair in a History of Terrorism postulates that the "fundamental terrorism is not ideology but an insurrectional strategy that is applied by diverse of people with different convictions politically". The contemporary (extra-ordinary) have nothing to be either nationalist or internationalist, but have cardinal values and similar mental makeup. The contemporary terrorism involve people with similarities and closer to each other with same purpose and able to master tactics. New terrorists operate in small organization but well arranged structures with an extension into transnational with more diffusing without hierarchical.

In the ancients, terrorist had formalized grouping and geographically central point of reference, thereby, vivid traceable unlike the contemporary age terrorists groups. The presupposition that French Revolution is the genesis of terror has been refuted by some scholars who argue that it is professed as it was undertaken by the French state to intimidate those who were opposed to its regime (Hoffaman, 1998, p1). Admittedly, traditional terrorism has been in existence as early as $19^{\text {th }}$ Century, though the conditions valid from age to age and country to country.

With the end of the World War II, in the late 1960's, terrorist acts perpetually happened in dependent states colonies and newly liberated nation's states. The terrorist acts mainly are hijacking, hostage taking, bombing, kidnapping and assassination. Neumann (2020) argues that methodology of terrorism attack target territories beyond national boundaries hence created emergence of international terrorism. Much that the old terrorism also attacked civilians, but the new terrorism attack mass of civilian population that seem to be a routine and attract international attention. In 2020, Media reported that Islamist insurgency had raged in Cabo Delgado Province in Mozambique and killed nearly 1,000 people and displaced tens of thousands $(10,000)$ more, the development that compelled the SADC Organ for Politics, Defence and Security to hold an Extraordinary Organ Troika Summit of Heads of State and Government to discuss security situation in northern Cabo Delgabo. The massive killing and displacements of civilians by terrorists in the area called for international involvement for speed intervention to restore peace and security. 
In 1963 terrorists launched an audacious assassination on John F. Kennedy the then President of United States of America whilst in Texas. The range of attacks continued, from 1968 to 1980 and the World recorded 6714 international terrorist events of which 2206 were in Western Europe. In 1980's the international terrorists' attacks took a different course to Middle East where in 1988, about 313 events were recorded. Meanwhile, in 1983, the Muslim extremists using bombs in Lebanon attacked American and French Military Organs killing 300 Americans and French Military personnel. The contemporary terrorist acts generated fear and discomfort.

In the contemporary age, the methodology executed by terrorists and insurgents are sophisticated in nature, therefore, the panacea to prevent and combat contemporary extra-ordinary terrorist should not be strategized in the manner of combating guerrilla warfare. The two are different in nature and quality. Terrorism is response to injustice driven by fanatical believers determined to despair injustice. The scourge can be combated by reducing grievances, stress and frustrations (Laqueur, 2001).

\section{AL-SHABAAB AND OTHER INSURGENT TERRORISM ACTIVISTS IN SADC}

Prior to the end of the cold war, the major threat among the states was conventional wars which were fought by state military sponsored on open battlefield with heavy weapons, between or among states, referred to as traditional war. However, the end of cold war and birth of globalization has seen the manifestation of new wars called "new" wars. These are not wars fought on a battlefield with arms, but nontraditional wars which are unforeseeable like, pandemic, epidemic, poverty, chronically diseases, insurgence and villain emergency terrorism. The new wars occur randomly and do not spare any state, hence this article has referred the 'new' wars to snake attack. The "Snake" attack in this case is focused on the al-Shabaab terrorists and other insurgents in SADC member states.

Since September 11, 2001 the tactics of terrorists and insurgency has evolved following development in technology that being adopted to geopolitical changes (Shaffer, 2018). With the development the insurgent are able to resort to sophisticated means in conducting their activities. To understand what spur violence among the society by insurgents, it requires an engagement of the affected groups. The emerging of terrorist groups or insurgents comes with a cause. With the mushrooming of secession across SADC states, the legitimate governments through SADC region are necessitated to embark on counter terrorism strategies together aimed at brawling plans to secede by the radical group. There are emerging terrorists and insurgent groups in Southern Africa such as al-Shabaab in Somalia, Allied Democratic Forces in DRC, Front for the Liberation of the Enclave (FLE) in Angola and the Islamic insurgent in Cabo Delgado Province of Mozambique (Abu-bashal, 2020; www.counterextremism.com).

The al-Shabaab terrorist group emerged as a youth wing for the Islamic Counts Union (ICU) together with the collection of neighborhood Shevia Counts established in 2004 to fill Somalia's government void of the 1990s. Albeit, upon invasion of Somalia and overthrowing of the Counts Union in 2006 by Ethiopia with the support of USA, the Youth wing under the leadership of late Aden Hashi Ayro who had strong links with Al-Qaeda was transformed from a fundamentalist to insurgency and gained control of Central and Southern Somalia (Garlenstein-Ross, 2009). 


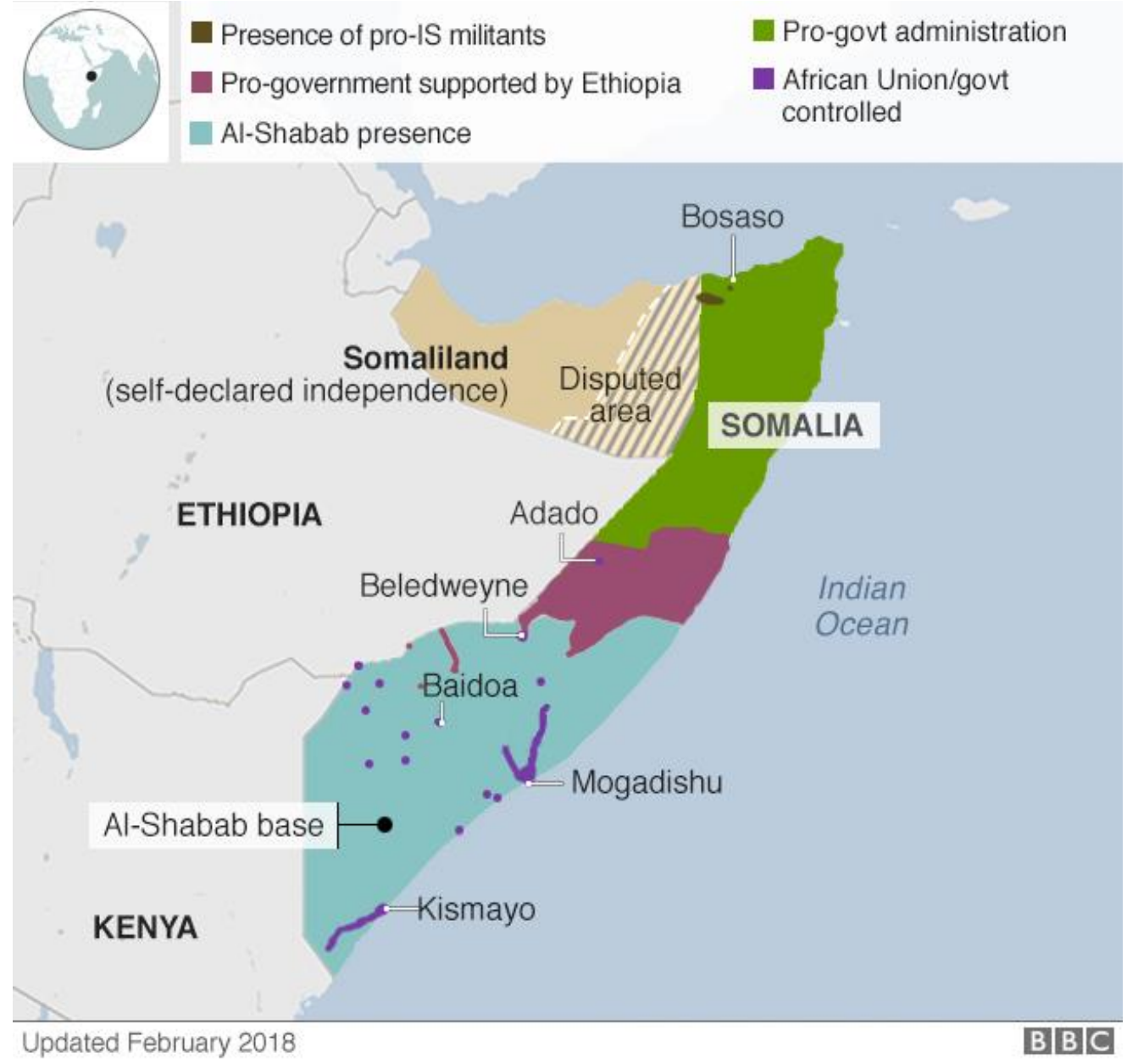

Fig 1:- Areas dominated by al-Shabaab in Somalia. Source: BBC December, 2017

In 2011 the African Union (AU) deploying 22,000 troops carried out offensive operation in Mogadishu Capital and hit the vital port of Kismayo which was earning alShabaab with a lot of money through the cut in charcoal trading, thereby, forcing them out of the Capital. Besides, America under the presidency of Donald Trump has continued with air strikes as per Pentagon plan despite killing Aden Hashi Ayro the leader and his successor Ahmed Abdi Godane.

Somali after colonialism from Italy and Britain suffered setbacks of famine, military dictatorship and civil, lack of internal order precipitated the hard-hitting Islamist group that acquired international prominence like al Shabaab. The al Shabaab carried out dirty war and spearheads the insurgency against Ethiopia and Somali government forces from 2006 when it was created as a special unit Islamic Counts Union Military. al Shabaab accused ICU of being cowards who were failing to advocate to true Islam of promoting Shariah Law and the dream of an Islamic state of being ruled by Shariah Law.

Hansen (2020) laments that Al-Shabaab undertook massive attacks in Somalia and Kenya that prompted Kenya and Ethiopia to combine efforts under the African Union Mission in Somalia to deploy troops to between
2012 and 2016 that contained the terror group. "The alShabaab attacked Westgate Mall, Garisa University and Dusit Hotel Complex in Kenya". Morier-Genoud (2019) postulate that the insurgents that had held Mozambique northern Cabo Delgabo for 17 months was confusing as nobody really knew who the insurgents were, but roots indicate that they were behind al-Shabaab terror group of Somalia. The group was at first confined to religious debates, practice and opposition to the secular state.

\section{$>$ Insurgent activists in SADC}

Terrorism phenomenon in this article includes the insurgents being conducted in SADC states; hence, it examines the preparedness of SADC member states in combating the threats of terrorism perpetrated by emergency villain terrorists in the new war especially, the al-Shabaab of Somalia. SADC member states are perceived to be immune to terrorism due to the enjoyment of peace and stability in connection to the activity as few incidences or null are recorded. Admittedly, there are sporadic incidences of insurgents related to terror among SADC states like Angola, DRC, and Mozambique. 


\section{- Angola- Front Liberation Enclave (FLC)}

Angola has never experienced incident of Islamist terrorism since it gained independence from Portugal in 1975 following a protracted guerrilla struggle since 1950. The country later also countered prolonged internal conflict between UNITA and MPLA which ended in 2002, thereafter, the country has experienced peace and stability, even though, there are terrorism threats stanching from a nationalist movement in the oil-rich Northern Province of Cabinda. The U.S. Department of State's Overseas Security Advisory Council (OSAC), indicates that the only active terrorist group that carry out terrorist activities in Angola is Front for the Liberation of the Enclave of Cabinda (FLEC).
Porto (2003) since the decade before Angolan independence, FLEC has waged a low-level guerrilla movement, and has fractured and regrouped several times. In the period of 1990s and 2000s, the FLEC undertook several activities aimed at attacking a number of military and foreign targets within Angola with the most major and pronounced being the attack on a bus carrying the Togolese national soccer team, killing three and wounded nine. There have been frantic efforts to engage and negotiate with the Angolan government by FLEC but to no avail, as the government has put its foot down. In that perception, the group has today continued to launch small-scale attacks against military targets in Cabinda.

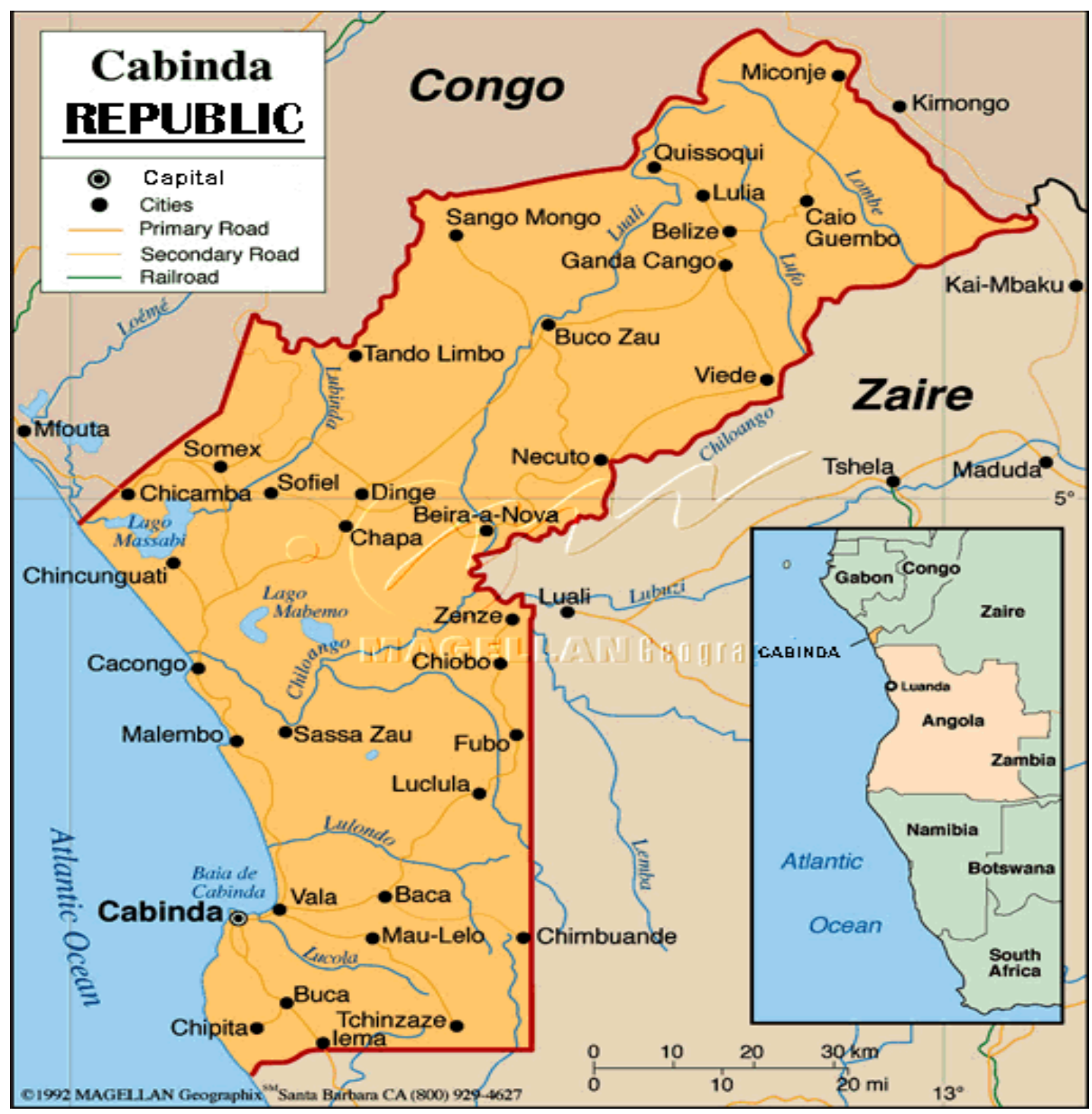

Fig 2:- Map for Cabinda disputed territory

Source: Magellan Geographix

The maneuvers to cut the oil-rich enclave of Cabinda from the rest of Angola began by President Mobutu of Zaire in mid-1970s with a view to accord Zaire to attain hegemony of the territory and request China to train troops from Cabinda Liberation Front so that eventually they overtake the MPLA, the deal which China turned down. Later, 2007 and 2008, attacks ensued by armed groups specifically targeted and attacked expatriates in Cabinda.
As of 2009 the Angolan government claimed that the war in Cabinda is over. However, sporadic attacks on government forces and expatriate workers have continued.

Meanwhile, in March 2017, the Angolan government through Anti-terrorism Unit arrested Kassim Tajideen, a prominent Hezbollah financier, on an INTERPOL warrant and extradited to the United States where he faced charges 
of fraud, money laundering, and violating global terrorism sanctions regulations. Tajideen, a U.S.-designated terrorist, had been living in Angola since 1990, where he operated a business empire that he used to contribute tens of millions of dollars to Hezbollah. The businesses included Golfrate Holdings Lda, Afri Belg Commerco E Industria and Grupo Arosfran Emprendimentos E Participacoes Sarl.

However, there is little threat from Islamic extremism in Angola, as there are few Muslims in the country. Approximately 90 percent of the country's population is Christian. The Angolan government does not officially recognize Islam, and was even accused by international media of "banning Islam" in 2013 after authorities destroyed two mosques in the capital, Luanda, though they were only destroyed because they had been built without permits. The government has effective local legal National Anti-terrorism Observatory and Ant-money Laundering/ Counter Terrorism Finance as per UN plan.

\section{- DRC-Allied Democratic Force (ADF)}

The Democratic of Republic of Congo (DRC) and Uganda experience Allied Democratic Forces (ADF) insurgency. The ADF, an offshoot of ISIS with external affiliations to al-Shabaab, has been responsible for the attack, in DRC. This onslaught is a reprisal for a strong offensive inflicted upon the ADF by the Armed Forces of the Democratic Republic of the Congo (FARDC). The DRC army's operation entailed a violent attempt to impede the progress of ADF rebels, who began infiltrating the nation's eastern border with Uganda, where the rebel group was founded in 1995.

The ADF terrorist were exploiting the geographically advantageous area of heavily forested DRC-Uganda border for the metastasis of the terrorism organization to nations outside of Uganda, as it provides the insurgents nearly unfeasible to identify. Terrorist groups operating in rainforest regions have been known to take advantage of this strategic geography by dressing in uniforms with camouflage colors, such that the rebels are nearly impossible to discern from the surrounding rainforest. This strategy has been employed on numerous occasions by Boko Haram insurgents.

In the Democratic Republic of Congo (DRC), the scourge of illegal resource acquisition and smuggling has been taking on a new dimension with terrorist groups becoming increasingly involved (Gatimu, 2016).

\section{- Mozambique - Ansar al-sunna Insurgency}

Ansar al-Sunna is a native extremist in Mozambique that has been terrorizing civilians with the support of alShabaab through training and the Islamic State of Iraq and the Levant. The insurgent started in 2015 in the northern districts of Cabo Ghabo as religious movement by among the activists of al-Shabaab who ran away to Tanzania and Kenya (GIATOC, 2020). The grouping is hoodwinking and targeting mainly youths with promises to fix unemployment, corruption and resolve inequalities in distribution of wealth. Ansar al-Sunna is leader by Abdul Faizal, Abdul Ramane, Salimo, Nuno Rename and Ibn Omar whose source of funding is dependent on heroin and ivory trading.

The attack was initiated in October, 2017 and Insurgents aggressively advanced to Cabo Delgado by March, 2020 to control territory in the region especially the key transport routes for legal and illegal commodities. The situation created an acute humanitarian impact on the local populace henceforth, fears arose that it may have a destabilizing effect on the wider region, and may deteriorate further than the current outbreak of violence, which has left many dead and an estimated 180,000 displaced.

"Government forces have been unable to stop the militants, even with the help of foreign mercenaries, and local security services are known to be ill-equipped and poorly trained". GIATOC (2020) reports that the insurgency does not appear to have a name universally agreed upon by all of its offshoots, though some attacks last year were claimed by a group calling it "Islamic State Central Africa Province." Locals also refer to it as" alShabaab, though there is no evidence of a link between the fighting in Mozambique and the terrorist group based in Somalia".

In May, 2020 four leaders of the SADC member states held SADC Extraordinary Organ Troika Summit on Politics, Defense, and Security Cooperation but failed to come up with a clear road up to deteriorating security situation in Mozambique following a formal request to the regional body. The SADC members merely agreed to ensure that peace and security in Cabo Delgabo prevails without clearly elaborating how the regional body will quench the insurgent activities. The militant insurgency in the northern Cabo Delgabo province have been displacing and killing innocent civilians, but the SADC merely resolved to continue sharing of information without stating the actual intervention that would be executed (Moyo, 2020).

\section{SADC STRATEGIES TO SCUFFLING TERRORISM AND INSURGENCY}

SADC is a regional block comprising sixteen (16) member states, and various objectives have been established inter alia to " promote peace and security within the region" ( Lautier, 2014). The emergence of the "new war' which is the 'snake attack' concept in the name of terrorist insurgency has not insulated SADC states. The 'snake' attack has implications on the territorial integrity, human security, and social, economic development, security stability and sovereignty which demand for adequacy and effective response by the region (Galadima \& Ogbonnaya, 2018).

The region is not an insulated region against terrorism, since the states are endowed with permissive factors exposing them to threats of international terrorism. 
In July, 2005, Zambia arrested Mr. Haroon Rashid Aswat in connection with the July 7 bombings in London and was handed over to the US authority (The Guardian, 2005). The case of Aswat is not unique as many SADC States have experienced sporadic incidences, which have been discussed in the preceding paragraphs. It is not doubtful that the region needs to provide covert strategy with major impact to subdue the powers of al-Shabaab activities.

Laqueur (2000) argues the combating of terrorism demand for comprehensive instrument mechanism, that criminalize any acts associated with terrorism as per United National Resolutions 1373 of 2001 (https://www.un.org) Terrorism poses a danger to the security, economic, social and political growth of States. The fundamental human rights of people community are always disturbed due to the complicated and damaging nature of the phenomenon through brutal massive killings, displacements and wounding.

In line with the UN Security Council Resolution 1373, in 2015 the SADC member states engaged into establishment of regional instrument framework for Counter-Terrorism, and three workshops were held in Namibia, Zimbabwe and Lusaka involving experts from Africa Centre for Studies and Research on Terrorism (CAERT), United Nations Counter-Terrorism Centre (UNCCT), SADC Organ Early Warning Unit. SADC Report (2019), during SADC $21^{\text {st }}$ Ministerial Committee of the Organ on Politics, Defence and Security Cooperation the Regional Counter Terrorism Strategy and Plan was approved aimed at preventing and combating terrorism and transnational organized crime anchoring on four pillars of United Nations Global Counter-Terrorism Strategy thus; Measures to prevent and combat terrorism; Measures to address the conditions conducive to the spread of terrorism; Measures to build States' capacity to prevent and combat terrorism and to strengthen the role of the United Nations system in this regard; and Measures to ensure respect for human rights for all and the rule of law as the fundamental basis of the fight against terrorism. The strategy call on all Member states to ensure its implementation at the national, regional. Furthermore, all member states were mandated to espouse the strategies to prevent and combat terrorism and enhance cooperation at all levels aimed at disrupting threats of terrorism (https://www.sadc.int).

Rifer (2005, p, 1) in the study of SADC and Terrorism, postulate that SADC member states denote the willingness to scuffle terrorism, but were hindered by various challenges. Imperatively, the UN Resolution 1373 which mandates all member states inclusive of SADC states to thwart all activities relating to terrorism, being financing, assistance has not been accorded the due diligence required in the implementation by SADC.

The UN has a clear mandate to undertake antiterrorist actions, (Rifer, 2005) but beyond the protocol would itself seem to charge the organ with confronting evolving security threats, like international terrorism. Rifer (2005) cites;
Article 2.2. a charges the organ to "protect the people and safeguard the development of the Region against instability arising from the breakdown of law and order, intra-state conflict, inter-state conflict and aggression'. Although terrorism isn't specifically mentioned, it certainly represents a breakdown of law and order, is an act of aggression, and is something against which 'the people' deserve protection.

Article 2.2.i obliges the organ to 'develop close cooperation between the police and state security services of State Parties in order to address: (i) cross border crime; and (ii) promote a community-based approach to domestic security'. This point clearly should apply to terrorism given its nature; it being a trans-national threat and a lawenforcement issue as much, or more, than it is a military issue.

Articles 11.2.a.iii and 11.2.b.iv give the organ jurisdiction over 'conflict which threatens peace and security in the Region or in the territory of another State Party'. Although it is difficult to define terrorism as a conflict per se, the adoption of Resolution 1373 declares it to be a threat to global peace and security, and therefore a threat to peace and security both in the region and within any member state. Article 11.2.c gives the organ authority to act in concert with the UN Security Council.

Article 11.1.d instructs the organ to 'seek to ensure that the State Parties adhere to and enforce all sanctions and arms embargoes imposed on any party by the United Nations Security Council'. Security Council Resolution 1373 effectively declares an embargo on all terroristrelated financing and support, and taken in this context, $S A D C$ - and specifically the security organ - is obliged to ensure that all member states take the appropriate measures to that end.

Notwithstanding, (SADC Report, 2002) the member states as formal statement of intent approved a Declaration on Terrorism to eliminate and foster security within SADC and world over and ratified legal instruments for ending terrorism and cooperation at all levels. In that vein, the region has established and adopted a number of protocols on the transnational threats inter alia; human trafficking, drug trafficking, small arms smuggling, cooperation in Wildlife Law enforcement. In a visit to INTERPOL Regional Bureau in November, 2018, Her Excellency Dr. Stergomena Lawrence Tax, SADC Executive Secretary in Zimbabwe, appreciated the SADC Framework Agreement with INTERPOL that it serves as platform for cooperation in preventing and combating terrorism, cyber crime as well as other organized crimes (SADC Report, 2018). The region has made strides through Agreements, protocol like East and Southern Africa Anti-Money Laundering Group (ESAAMLG) meant to suppression of the financing of terrorism, but the region lacks far much behind from scuffling the scourge. 
As Rifer (2005) laments that SADC region is engulfed by acute imbalance and inequities to which on one hand, South Africa is in many ways a developed nation, while other countries in the region like Malawi and Mozambique face challenges. The inequity prevalence among SADC states create an awkward development to effectively implement the Counter-Terrorism Strategy as funding of certain programme become difficulty. Chingono \& Nakana (2009) it is not a disputable fact that there is very minimal trade between and among member states, save for South Africa due to economic disparities and inequities among Member States. This accounts for the low growth of trade between member states and the subsequent heavy external debt. In the region, there is relative or sometimes absolute abandoning of rural African populations thereby causing acute poverty since the incomes are very low. The other hiccup that the SADC region faces to prevent and combat terrorism is national conflict by some states. For instance, the DRC, riven by conflict for a decade, is still struggling to emerge as a functioning state.

Rifer (2005) "Faced with different priorities, challenges, and capabilities, there are wide disparities in the willingness and ability of individual SADC states to confront the issue of terrorism. In a region with the world's highest prevalence rates of HIV/AIDS, a region plagued by conflict, poverty, and underdevelopment, it is not hard to understand why. Still, while terrorism may not rise to the priority that it enjoys in the West, or even in other parts of Africa, its potential implications warrant that SADC states take the issue seriously. Indeed, prudent action now could prevent terrorism - and any perceived vulnerability to it from becoming a greater issue in the future".

The setting of priorities and challenges faced by member states differ. Currently, the member states world over are embroiled with the pandemic Corona virus Disease (COVID-19) which has claimed about 325,000 by May 20, 2020 (Medical Press, 2020). Therefore, it is an impingement for a SADC member state to prioritize the funding of terrorism ignoring the fight against the spread of COVID-19.

In discussing the weakness of SADC in combating terrorism, it established that member states are posed with porous borders, inadequate and under trained security personnel, lack of update equipment and border post and increased flow of illegal migrants. The challenge of porous border affects many states. Some Scholars have observed that taking advantage of a porous border, Palestinian nationals easily accessed Israel in search of employment and basic welfare needs; however, the influx of the Palestinians also provided easy access for terrorists to infiltrate Israel through the West Bank. This situation compelled the Israeli Government in 2002 to erect a security "fence" fifty to seventy meters (50-70ms) wide consisting two layers of Smart fence and a buffer (Isoke, 2015). Similarly, the region is faced with social exclusion and corruption, lack of effective and consistent information sharing among security and other agencies at local, national and at regional levels.

\section{CONCLUSION}

The emancipation of al-Shabaab and insurgents some with international links pose a threat to the peace and security of SADC region. It is high time the region ensured that the strategies to scuffle the scourge were enforced and legal frameworks are putting in place. SADC member states are endowed with permissive factors such as minerals, unemployment, collapsed economy, and poverty exposing them to threats of International terrorism, especially States like South Africa, Tanzania, Congo DRC, Mozambique, Mauritius, Zambia and Zimbabwe. Unlike the West Africa bloc ECOWAS, SADC does not have a standing army. But individual countries have in the past deployed their armies to quell security threats in other member countries. Zimbabwe sent troops to the Democratic Republic of Congo in 1998, and South Africa sent troops to Lesotho the same year. The SADC region has challenges to attain the capacity to scuffle terrorism without international involvement owing to the advanced factors.

\section{REFERENCES}

[1]. AFP Reuters Mozambique 2020

[2]. Amnesty International. (2009). Suppression of Terrorism Act. Undermines Human Rights in Swaziland

[3]. Cannon, J. Brendan \& Pkalya, Ruto Dominic. (2017). Why al-Shabaab Attacks Kenya: Questioning the Narrative Paradigm, p 836-852

[4]. Centre on Global Counter Terrorism Cooperation. Implementing the UN Global Counter Terrorism Strategy in Southern Africa, September ,2007.

[5]. Chingono, M. \& Nakana, S. (2009). The challenges of regional integration in Southern Africa. African Journal of Political Science and International Relations 3(10), pp.396-408.

[6]. Galadima, S. Habu \& Ogbonnaya, M. Ufiem. (2018). Regional responses to Security and Development Challenges in East and Southern Africa. Leasons and Way forward.

[7]. Gartenstein-Ross, Daveed. (2009). The strategic Challenges of Somalia's Al-Shabaab

[8]. Gatimu, Sebastian. (2016). Is the Illegal Trade in Congolese minerals financing terror? ISS Today www.counterterrorism.com $>$ contries $>$ angola

[9]. Global Initiative Against Transnational Organised Crime (GIATOC).

[10]. Golder, Ben \& William, Gerg. (2004). What is Terrorism? Problem of Legal Definition. UNSW Law Journal Volum 27 (2),

[11]. Hansen, Jarle Stig. (2013). Al-Shabaab in Somalia: The History and Ideology of a Militant Islamist Group.

[12]. Hoffman, Bruce. (1998). Countering the New Terrorism Chapter Two: Terrorism Trends and Prospective.

[13]. Lautier, Jonathan. (2014). Africa Conflict Monthly Monitor, Volume 2014, issue 03 p 54-59

[14]. Manzongo, John. (2020). Southern Africa. Zim Hosts SADC Troika Summit on Moza 
[15]. Mayerson, Jake. (2019). Terror in the Congo: 15 Dead in Radical Islamist Attack. IR INSIDER

[16]. Morier-Genoud, Eric. (2019). How a local Mozambique Islamic group became Africa's latest terror threat. QUARTZ AFRICA

[17]. Neumann, R. Peter. (2020). Terrorism in the $21^{\text {st }}$ Century. The rule of Law as guideline for German Policy.

[18]. Porto, G. Joao. (2003). Notes on a soon-to-beforgotten war. Institute of Security Studies.

[19]. Rifer, Michael. (2005). SADC AND TERRORISM .Where is the regional strategy? Volume 14, No 1

[20]. Ruby, L. Charles. (2003). The definition of Terrorism. British Journal of Development Psychology

[21]. Saul, Ben. (2005). Definition of Terrorism in the UN Security Council 1985-2004. Chinese Journal Internal Law, Volume 4, issue 1 pages 141-166.

[22]. Shaffer, Ryan. (2018). Changes and Drivers in Contemporary Terrorism. Terrorism and Political Violance Journal Volume 30, issue 3 pages 544-552

[23]. The Gurdian .(2005). World News. Zambia to deport Terror Suspect. Retrieved from www.theguardian.com 10/12/19 at 5:50pm

[24]. Whittaker, J. David. (2012). The Terrorism Reader. Fourth Edition. Rouitledge

[25]. Zalma, Army. (2020). Causes of Terrorism. www.though.com $>$ terrorism $>$ History

[26]. https://doi.org/10.1093/chinesejil/jmi005

[27]. BBC News 2017 Dec 22. Who are Somalia's AlShabaab

[28]. SADC Report 20 July, 2019 